AperTO - Archivio Istituzionale Open Access dell'Università di Torino

\title{
Randomized Controlled Trials Evaluating Effect of Television Advertising on Food Intake in Children: Why Such a Sensitive Topic is Lacking Top-Level Evidence?
}

\section{This is the author's manuscript}

Original Citation:

Availability:

This version is available http://hdl.handle.net/2318/1523176

since 2015-12-10T15:13:08Z

Published version:

DOI:10.1080/03670244.2014.883976

Terms of use:

Open Access

Anyone can freely access the full text of works made available as "Open Access". Works made available under a Creative Commons license can be used according to the terms and conditions of said license. Use of all other works requires consent of the right holder (author or publisher) if not exempted from copyright protection by the applicable law. 


\section{(2) \\ UNIVERSITÀ DEGLI STUDI DI TORINO}

This is an author version of the contribution published on:

Questa è la versione dell'autore dell'opera:

Ecology of Food and Nutrition, Volume 53, Issue 5, 2014, doi:10.1080/03670244.2014.883976

The definitive version is available at:

La versione definitiva è disponibile alla URL:

http://www.tandfonline.com/doi/full/10.1080/03670244.2014.883976 
Randomized Controlled Trials Evaluating Effect of Television Advertising on Food Intake in Children: Why Such a Sensitive Topic is Lacking Top-Level Evidence?

Authors

Dario Gregori ${ }^{1}$, Simonetta Ballali ${ }^{2}$, Maria Gabriella Vecchio ${ }^{2}$, Antonella Silvia Scirè ${ }^{2}$, Francesca

Foltran $^{1}$, Paola Berchialla ${ }^{3}$

${ }^{1}$ Unit of Biostatistics, Epidemiology and Public Health, Department of Cardiac, Thoracic and Vascular Sciences, University of Padova, Padova, Italy

${ }^{2}$ PROCHILD Onlus, Trieste, Italy

${ }^{3}$ Department of Clinical and Biological Sciences, University of Torino, Torino, Italy

Address correspondence to

Dario Gregori,

Unit of Biostatistics, Public Health and Epidemiology,

Department of Cardiac, Thoracic and Vascular Sciences,

University of Padova,

Via Loredan, 18, 35131

Padova, Italy.

E-mail: dario.gregori@unipd.it 


\begin{abstract}
The aim of this study was to perform a systematic review of evidence coming from randomized controlled trials (RCT) aimed at assessing the effect of television advertising on food intake in children from 4 to 12 years old. Randomized controlled trials were searched in PubMed database and included if they assessed the effect of direct exposure to television food advertising over the actual energy intake of children. Seven studies out of 2166 fulfilled the inclusion criteria. The association between television advertising and energy intake is based on a very limited set of randomized researches lacking a solid ground of first-level evidence.
\end{abstract}

KEYWORDS child obesity, food consumption, food preference, snacks, TV advertising

\title{
INRODUCTION
}

In recent years, obesity has reached epidemic status, affecting not only developed country but also developing ones (WHO 2000). Obesity levels don't show an homogeneous distribution, ranging from below 5\% in China, Japan and certain African nations, to over 75\% in urban Samoa, and even within the same countries, a high variance can be seen, as for example in China, where figures reach almost $20 \%$ in some cities.

Where national data are available, adiposity has increased in both preschool and school-aged children in nearly every country studied (von Kries et al. 2012). However, large variations in secular trends do appear across countries, and these relate to the degree of economic development and urbanisation (Wang and Lobstein 2006). Childhood obesity and overweight are at the roots of adult diseases development, including type 2 diabetes, fatty liver disease, and endocrine and orthopaedic disorder (Lobstein, Baur, and Uauy 2004).

The complexity underlying obesity has been often simplified to a dichotomy between energy intake and energy expenditure (Crowley, Yeo, and O'Rahilly 2002), considering unregulated food consumption as the main responsible of increased energy intake. Easy access to energy-rich foods 
and drinks, food marketing through television and other media, increased use of video entertainment and computer games playing, have all been suggested as promoting the "toxic" or “obesogenic” environment (Ebbeling, Pawlak, and Ludwig 2002; Egger and Swinburn 1997; Kumanyika et al. 2002).

Television is part of worldwide home setting; therefore TV-related sedentary time has been investigated in order to assess its relation with obesity development. Results have not being homogeneous, ranging from proven association (Lobstein et al. 2004) to no influence at all on energy intake (Jackson et al. 2009). Television is suspected to be linked to a reduction in physical activity whilst advertising seems to promote an overconsumption of food high in fat and sugar (Caroli et al. 2004; Carter et al. 2011). Most of the studies focusing on this subject have been conducted in the Anglo-Saxon context (Adams et al. 2009; Adams et al. 2012; Crespo et al. 2001), showing a correlation between time spent watching television and nutritional status of the subjects involved. Dietz and Gortmaker demonstrated in 1985 a significant, positive association between hours of television viewed and obesity in children and adolescents, and since then these results were confirmed in several studies (Boone et al. 2007; Crespo et al. 2001; Jackson et al. 2009; Jago et al. 2005; Mendoza, Zimmerman, and Christakis 2007). There are two main aspects considered when investigating the effects of TV on childhood obesity: (1) reduced energy expenditure linked to screen time (Scaglioni et al. 2011) and (2) augmented energy intake driven by advertising and snaking (Rennie, Johnson, and Jebb 2005). When considering the problem from the latter perspective, the main hypothesis is that the effect of TV viewing time on childhood obesity may be independent of physicalactivity status and may be attributed to the increased total energy intake during TV watching (Manios et al. 2009), statement supported for example from Jackson's results (Jackson et al. 2009) but contradicted in Schmidt and colleagues' (2012) systematic review, which highlights that the studies on obesity intervention considered have reduced screen-media use in children, but points out as well that there are several research gaps, including a relative paucity of 
studies targeting young children and minorities, limited long-term follow-up data, and few studies targeting removing TVs from children's bedrooms.

From the point of view of advertising, several important reviews reported already on the effect that TV advertising has on influencing children's preferences and choices (Hastings et al. 2003; Kunkel et al. 2004).

Nevertheless, very small attention has been given at today to the effect of TV advertising on the actual intake of children. Indeed, even since the very seminal experimental work (Gorn and Goldberg 1982) on effects of TV advertising on child behaviors with respect to food, the causal link between food-choice and food-consumption has been always hypothesize but seldom investigated as a research outcome. The preference for a certain food cannot be however directly translated in terms of actual consumption of that food, being modulated by a series of demographic, socioeconomic (Drewnowski 1997) and perhaps genetic factors (Cecil et al. 2008). The aim of this article is to review evidences on experimental research focused on the relationship between children's exposure to TV advertising and their actual food intake.

\section{METHODS}

Randomized controlled trials (RCTs) assessing the direct influence of food advertising on food consumption in children during TV viewing, were evaluated. The medical subject-headings terms that were combined and researched on the PubMed database were: TV, television, advertisements, screen time, weight, overweight, intake, consumption, eating, and child.

Kilocalories (Kcal) and grams (gr) were chosen as selection criterion to quantify children's food intake. No restrictions on time or language were applied.

All included abstracts were independently identified by two reviewers, and paper selection was independently performed, in order to select the articles fulfilling the inclusion criteria. All studies whose outcome was food intake's quantification during or immediately after screen time, were chosen. A summary of the selection criteria and search strategy is provided in table 1. 
For each paper included in the review, authors, study design, population (dimension and age group), aim of the study, setting and intervention, outcome of interest, and results, were recorded. The methodological quality of the studies was assessed using the Jadad scale for RCTs (Jadad et al. 1996).

\section{RESULTS}

Up to March 2012, 2,166 items were found. Seven studies, targeted to investigate the food intake during or after exposure to food advertising (either on TV or videogames) compared to neutral (non-food) commercials, were identified as pertinent. The main characteristics of the studies are shown in table 2. Quality of studies, evaluated on the 0- to 5-point Jadad scale, was low, having an average score of 1.57 and never being higher than 2 (table 3).

The results of Halford and colleagues (Halford et al. 2007; Halford et al. 2008) showed that total kcal intake was significantly higher after exposure to food advertising. Also, Harris and colleagues (2009) and Dovey and colleagues (2011) observed a relevant higher consumption of snacks during food advertising.

One study from Anschutz and colleagues (2009) reported on the potential existence of a gender effect, demonstrating that snack intake was different among girls and boys. Indeed, food intake in boys was higher when watching food advertising, whereas snack intake in girls was slightly lower when exposed to food advertising.

In a study by Halford and colleagues (2004), the effect of food advertising on food intake was reported as being potentially modulated by the overweight or obese status of the child. Children were divided into three weight status categories: lean, overweight, obese; and food intake in the three groups was estimated further to two categories: an exposure to food, and non-food advertising. Results showed a major consumption of snacks among obese and overweight children, both in the food advertising group and in non-food one. 
The role of maternal pressure to control weight gain has been also investigated as a potential modulator of the children's eating as a reaction to food advertising (Anschutz, Engels, and Van Strien. 2010). The study showed that kids, who were encouraged from their mothers to be thinner, ate more especially when exposed to light food commercials than when exposed to neutral advertising. In contrast, children who perceived no maternal pressure ate more when exposed to neutral commercials than when exposed to either energy-dense or light food commercials.

\section{DISCUSSION}

A first finding from the current review —in spite of the broad coverage on the subject, attesting to intense research activity — was that very few papers presenting RCT as a chosen study design ( 7 out of 2,166$)$, were targeted to actual food intake as an outcome. This finding confirmed the initial impression at the ground of our investigation that, although there's global interest on the subject and strong recommendation to provide higher-level evidence (Barton 2000), studies evaluating actual food consumption using a higher-level study design, are still lacking.

The fact that this situation is an incontrovertible pitfall, is in line with Fenton and Fenton's (2011) considerations, namely that nutrition science should not and need not be complacent with lower levels of evidence than is required for other branches of medical science. In this perspective, also in the nutrition field, RCT in one of its variant forms is the study design that best permits strong causal inference concerning the relationship between a factor and any specific outcome (Blumberg et al. 2010). In addition, all the RCTs considered in this review showed an association between TV advertising and energy intake; but all the authors stressed the fact that their study was only a proof of concept, taken the small samples considered and the very specific age groups, and lacking the ability to prove causality (Adamson 2004).

Gender seemed to influence eating behavior in several studies (Anschutz et al. 2009; Halford et al. 2008), showing that an increased intake after exposure to food commercials occurred mostly in boys. A possible explanation for this finding was that boys may have a higher tendency to eat in response to visual food stimuli than do girls (Snoek et al. 2007; Van Strien and Bazelier 2007). 
Boys are often found to have less self-control than do girls (Turner and Piquero 2002), and low selfcontrol has been found to be related to a higher intake of saturated fat (Wills et al. 2007). Previous research showed that even very young girls experience more sociocultural pressure, eating disturbances, and/or body dissatisfaction than do their male peers (Gardner, Sorter, and Friedman 1997; Wood, Becker, and Thompson 1996). Thus, boys may actually have shown a normal response to food commercials, whereas girls may have suppressed their natural response to the food commercials (Doeschka et al. 2009). Another concept that appeared influencing food intake was food neophobia, considered especially in a study by Dovey and colleagues (2011); the study showed that acceptance or rejection of healthy foods has critical consequences for health during childhood and throughout the lifespan.

Paradigms which examine the role of food neophobia in determining the nature of a child's response to television food advertising, may enable the identification of children potentially at risk of increased weight gain, earlier in their development (Dovey et al. 2011). The nature of children's response to food advertisements for healthy and unhealthy foods, in part determined by food neophobia, may increase caloric intake (Dovey et al. 2011).

Parents' influence was analyzed in depth in a paper by Anschutz and colleagues (2010) and as seen also in other studies (Brown et al. 2008; Scaglioni, Salvioni, and Galimbeti 2008), a restraining behavior was peered by an increased intake of food. Children appeared to be more influenced by TV advertising when the mothers were encouraging them to be thinner, while no significant association was found when considering maternal concern for children's weight and TV commercials.

As considered at the very beginning, methodological issues in this field of behavioral nutrition research appear to be exposed to potentially highly bias results, limiting therefore the possibility to extend these results to the population level. Similar considerations have been recently made from Vyth and colleagues (2012), again considering a specific and debated issues pertaining to behavioral nutrition. With their first study providing an overview of the methodological quality of 
current front-of-packaging labeling research, Vyth and colleagues concluded that few methodologically sound studies are presently available, moreover suggesting the urgent need of longitudinal, randomized, controlled design in a real-life setting. In line with what was observed by Vyth and colleagues, the quality of the seven studies considered in this review was much lower than commonly accepted standards in other research fields.

In the same stream sets the present review, pointing out that standardized methods to assess the interaction between TV advertising and food intake in children are needed, in order to provide rigorous evidence to rulers and policy makers, in a field yet strongly influenced by familiar behavioral aspects and biology.

In conclusion, considering the insufficient data incident to this topic and the poor methodological quality of the few available evidences, more RCTs addressing the relationship between TV advertising and food intake in children, perhaps using strong outcomes like energy intake instead of food preferences, are required to deepen knowledge on causal relationships and therefore to set the root for incisive prevention.

\section{FUNDING}

The work has been partially covered by an unrestricted grant from the University of Padova and by an unrestricted grant from Prochild ONLUS (Italy). In addition, the research did benefit by an unrestricted grant from the Italian Ministry of Foreign Affairs under the program "Programmi di alta rilevanza scientifica e tecnologica Italia-Messico."

\section{AUTHORS' CONTRIBUTION}

Dario Gregori conceptualized and drafted the manuscript, Simonetta Ballali, Maria Gabriella Vecchio, Silvia Scirè,and Francesca Foltran reviewed the literature and contributed to drafting the manuscript, Paola Berchialla critically revised the manuscript and contributed to drafting its last version. 


\section{REFERENCES}

Adams, J., K. Hennessy-Priest, S. Ingimarsdottir, J. Sheeshka, T. Ostbye and M. White. 2009. Food advertising during children's television in Canada and the UK. Archives of Disease in Childhood 94 (9): 658-662.

Adams, J., R. Tyrrell, A. J. Adamson and M. White. 2012. Socio-economic differences in exposure to television food advertisements in the UK: A cross-sectional study of advertisements broadcast in one television region. Public Health Nutrition 15 (3): 487-494.

Adamson, J. 2004. Evaluation of studies of causation (etiology). Evidence Based Nursing 7 (2): 3640.

Anschutz, D. J., R. C. Engels and T. Van Strien. 2009. Side effects of television food commercials on concurrent nonadvertised sweet snack food intakes in young children. American Journal of Clinical Nutrition 89 (5): 1328-1333.

Anschutz, D. J., R. C. M. E. Engels and T. Van Strien. 2010. Maternal encouragement to be thin moderates the effect of commercials on children's snack food intake. Appetite 55 (1): 117-123. Barton, S. 2000. Which clinical studies provide the best evidence? The best RCT still trumps the best observational study. BMJ 321 (7256): 255-256.

Boone, J. E., P. Gordon-Larsen, L. S. Adair and B. M. Popkin. 2007. Screen time and physical activity during adolescence: Longitudinal effects on obesity in young adulthood. International Journal of Behavioral Nutrition and Physical Activity 4:26.

Blumberg, J., R. P Heaney, M. Huncharek, T. Scholl, M. Stampfer, R. Vieth, C. M Weaver, and S. H Zeisel. 2010. Evidence-based criteria in the nutritional context. Nutrition Reviews 68 (8): 478484.

Brown, K. A., J. Ogden, C. Vogele and E. L. Gibson. 2008. The role of parental control practices in explaining children's diet and BMI. Appetite 50 (2-3): 252-259. 
Caroli, M., L. Argentieri, M. Cardone and A. Masi. 2004. Role of television in childhood obesity prevention. International Journal of Obesity and Related Metabolic Disorders 28 (Suppl 3): S104108.

Carter, O. B., L. J. Patterson, R. J. Donovan, M. T. Ewing and C. M. Roberts. 2011. Children's understanding of the selling versus persuasive intent of junk food advertising: Implications for regulation. Social Science \& Medicine 72 (6): 962-968.

Cecil, J. E., R. Tavendale, P. Watt, M. M. Hetherington and C. N. A. Palmer. 2008. An obesityassociated FTO gene variant and increased energy intake in children. New England Journal of Medicine 359 (24): 2558-2566.

Crespo, C. J., E. Smit, R. P. Troiano, S. J. Bartlett, C. A. Macera and R. E. Andersen. 2001. Television watching, energy intake, and obesity in US children: Results from the third National Health and Nutrition Examination Survey, 1988-1994. Archives of Pediatrics \& Adolescent Medicine 155 (3): 360-365.

Crowley, V. E., G. S. Yeo and S. O'Rahilly. 2002. Obesity therapy: Altering the energy intake-andexpenditure balance sheet. Nature Reviews Drug Discovery 1 (4): 276-286.

Dietz, W. H. and S. L. Gortmaker. 1985. Do we fatten our children at the television set? Obesity and television viewing in children and adolescents. Pediatrics 75 (5): 807-812.

Doeschka J Anschutz, Rutger CME Engels and Tatjana Van Strien. 2009. Side effects of television food commercials on concurrent nonadvertised sweet snack food intakes in young children. american Journal of Clinical Nutrition 89:1328-1333.

Dovey, T. M., L. Taylor, R. Stow, E. J. Boyland and J. C. Halford. 2011. Responsiveness to healthy television (TV) food advertisements/commercials is only evident in children under the age of seven with low food neophobia. Appetite 56 (2): 440-446.

Drewnowski, A. 1997. Taste preferences and food intake. Annual Review of Nutrition 17 (1): 237253. 
Ebbeling C. B., D. B. Pawlak, and D. S. Ludwig. 2002. Childhood obesity: Publichealth crisis, common sense cure. Lancet 360 (9331): 473-482.

Egger, G., and B. Swinburn. 1997. An "ecological” approach to the obesity pandemic. BMJ 315 (7106): 477-480.

Fenton, T. R., and C. J. Fenton. 2011. Nutrition science mustn't accept a lower level of evidence. Nutrition Reviews 69 (7): 413-414; reply 415-416.

Gardner, R. M., R. G. Sorter, and B. N. Friedman. 1997. Developmental changes in children's body images. Journal of Social Behavior \& Personality 12:1019-1036.

Gorn, G. J., and M. E. Goldberg. 1982. Behavioral evidence of the effects of televised food messages on children. Journal of Consumer Research 9 (2): 200-205.

Halford, J. C., E. J. Boyland, G. Hughes, L. P. Oliveira, and T. M. Dovey. 2007. Beyond-brand effect of television (TV) food advertisements/commercials on caloric intake and food choice of 57-year-old children. Appetite 49 (1): 263-267.

Halford, J. C., E. J. Boyland, G. M. Hughes, L. Stacey, S. McKean, and T. M. Dovey. 2008. Beyond-brand effect of television food advertisements on food choice in children: The effects of weight status. Public Health Nutrition 11 (9): 897-904.

Halford, J. C., J. Gillespie, V. Brown, E. E. Pontin, and T. M. Dovey. 2004. Effect of television advertisements for foods on food consumption in children. Appetite 42 (2): 221-225.

Harris, J. L., J. A. Bargh, and K. D. Brownell. 2009. Priming effects of television food advertising on eating behavior. Health Psychology 28 (4): 404-413.

Hastings, G., M. Stead, L. McDermott, A. Forsyth, A. M. MacKintosh, M. Rayner, C. Godfrey, M. Caraher, and K. Angus. 2003. Review of research on the effects of food promotion to children. Glasgow, Scotland: Center for Social Marketing, University of Strathclyde Glasgow. Jackson, D. M., K. Djafarian, J. Stewart, and J. R. Speakman. 2009. Increased television viewing is associated with elevated body fatness but not with lower total energy expenditure in children. American Journal of Clinical Nutrition 89 (4): 1031-1036. 
Jadad, A. R., R. A. Moore, D. Carroll, C. Jenkinson, D. J. M. Reynolds, D. J. Gavaghan, and H. J. McQuay. 1996. Assessing the quality of reports of randomized clinical trials: Is blinding necessary? Controlled Clinical Trials 17 (1): 1-12.

Jago, R., T. Baranowski, J. C. Baranowski, D. Thompson and K. A. Greaves. 2005. BMI from 3-6 y of age is predicted by TV viewing and physical activity, not diet. International Journal of Obesity (London) 29 (6): 557-564.

Kumanyika, S., R. W. Jeffery, A. Morabia, C. Ritenbaugh, and V. J. Antipatis. 2002. Public Health Approaches to the Prevention of Obesity (PHAPO) Working Group of the International Obesity Task Force (IOTF). International Journal of Obesity \& Related Metabolic Disorders 26 (3): 425436.

Kunkel, D., B. L. Wilcox, J. Cantor, E. Palmer, S. Linn, and P. Dowrick. 2004. Report of the APA Task Force on Advertising and Children, 40. Washington, DC: American Psychological Association.

Lobstein, T., L. Baur, and R. Uauy. 2004. Obesity in children and young people: A crisis in public health. Obesity Reviews 5 (Suppl 1): 4-104.

Manios, Y., G. Kourlaba, K. Kondaki, E. Grammatikaki, A. Anastasiadou, and E. Roma-Giannikou. 2009. Obesity and television watching in preschoolers in Greece: The GENESIS study. Obesity (Silver Spring) 17 (11): 2047-2053.

Mendoza, J. A., F. J. Zimmerman, and D. A. Christakis. 2007. Television viewing, computer use, obesity, and adiposity in US preschool children. International Journal of Behavioral Nutrition \& Physical Activity 4:44.

Rennie, K. L., L. Johnson, and S. A. Jebb. 2005. Behavioral determinants of obesity. Best Practice \& Research Clinical Endocrinology \& Metabolism 19 (3): 343-358.

Scaglioni, S., C. Arrizza, F. Vecchi, and S. Tedeschi. 2011. Determinants of children's eating behavior. American Journal of Clinical Nutrition 94 (6 Suppl): 2006S-2011S. 
Scaglioni, S., M. Salvioni, and C. Galimberti. 2008. Influence of parental attitudes in the development of children eating behavior. British Journal of Nutrition 99 (Suppl 1): S22-25. Schmidt, M. E., J. Haines, A. O’Brien, J. McDonald, S. Price, B. Sherry, and E. M. Taveras. 2012. Systematic review of effective strategies for reducing screen time among young children. Obesity (Silver Spring) 20 (7): 1338-1354.

Snoek H. M., T. Van Strien, J. M. A. M. Janssens, and R. C. M. E Engels. 2007. Emotional, external, restrained eating and overweight in Dutch adolescents. Scandinavian Journal of Psychology 48:23-32.

Turner, M. G., and A. R. Piquero. 2002. The stability of self-control. Journal of Criminal Justice $30: 457-471$.

Van Strien, T., and F. G. Bazelier. 2007. Perceived parental control of food intake is related to external, restrained and emotional eating in 7-12-year-old boys and girls. Appetite 49:618-625. von Kries, R., H. Reulen, O. Bayer, C. Riedel, K. Diethelm, and A. E. Buyken. 2012. Increase in prevalence of adiposity between the ages of 7 and 11 years reflects lower remission rates during this period. Pediatric Obesity 8 (1): 13-20.

Vyth, E. L., I. H. Steenhuis, H. E. Brandt, A. J. Roodenburg, J. Brug, and J. C. Seidell. 2012. Methodological quality of front-of-pack labeling studies: A review plus identification of research challenges. Nutrition Reviews 70 (12): 709-720.

Wang, Y., and T. Lobstein. 2006. Worldwide trends in childhood overweight and obesity. International Journal of Pediatric Obesity 1 (1): 11-25. WHO. 2000. Obesity: Preventing and managing the global epidemic. Report of a WHO consultation. Technical Report Series 894, i-xii; 1-253. Rome: World Health Organization. Wills, T.A., C. R. Isasi, D. Mendoza, and M. G. Ainette. 2007. Self-control constructs related to measures of dietary intake and physical activity in adolescents. Journal of Adolescent Health 41:551-558. 
Wood, K. C., J. A. Becker, and J. K. Thompson. 1996. Body image dissatisfaction in preadolescent children. Journal of Applied Developmental Psychology 17:85-100. 


Table 1. Studies Selection Strategy

\begin{tabular}{|c|c|c|c|c|c|}
\hline String on PubMed & $\begin{array}{l}\text { No. of obtained } \\
\text { articles }\end{array}$ & $\begin{array}{l}\text { Selection criterion to } \\
\text { quantify children's food } \\
\text { intake }\end{array}$ & $\begin{array}{l}\text { Restrictions on time or } \\
\text { language }\end{array}$ & Outcome & $\begin{array}{l}\text { No. of adequate } \\
\text { articles }\end{array}$ \\
\hline $\begin{array}{l}\text { TV, television, advertisements, } \\
\text { screen time, weight, overweight, } \\
\text { intake, consumption, eating and } \\
\text { child }\end{array}$ & 2166 & $\begin{array}{l}\text { Kilocalories (Kcal) and } \\
\text { grams(gr) }\end{array}$ & None & $\begin{array}{l}\text { Food intake's quantification } \\
\text { during or immediately after } \\
\text { screen time }\end{array}$ & \\
\hline
\end{tabular}


Table 2. Studies Included in the Analysis

\begin{tabular}{|c|c|c|c|c|c|c|}
\hline $\begin{array}{l}\text { Reference } \\
\text { (authors, year) }\end{array}$ & Country & $\begin{array}{l}\text { Participants } \\
(N, \text { age })\end{array}$ & Aim of the study & Setting and intervention & Outcome of interest & Results \\
\hline Dovey 2011 & UK & $\begin{array}{l}66 \text { children aged } 5- \\
7 \text { years old } \\
(\text { male: } 34,51.5 \%)\end{array}$ & $\begin{array}{l}\text { Assessment of the effects } \\
\text { of advertisement type } \\
\text { (healthy, unhealthy foods } \\
\text { and toy) and food } \\
\text { neophobia status on } \\
\text { caloric intake by food } \\
\text { item and total intake after } \\
\text { viewing television. }\end{array}$ & $\begin{array}{l}\text { School. Children } \\
\text { watched a 14-min } \\
\text { cartoon embedded with } \\
\text { a selection of each type } \\
\text { of advert. After } \\
\text { watching, they were } \\
\text { offered a snack } \\
\text { consisting of } \\
\text { pre-weighed individual } \\
\text { servings of six snack } \\
\text { foods on a plate. }\end{array}$ & $\begin{array}{l}\text { Caloric intake after } \\
\text { viewing a cartoon } \\
\text { embedded with each } \\
\text { advertisement type: } \\
\text { total kcal consumed in } \\
\text { each condition and } \\
\text { individually for each } \\
\text { food item. }\end{array}$ & $\begin{array}{l}\text { For all children, total kcal } \\
\text { intake was higher } \\
\text { following the unhealthy } \\
\text { food ads compared to } \\
\text { both the healthy food } \\
\text { ads and toy ads. }\end{array}$ \\
\hline Anschutz 2010 & Netherlands & $\begin{array}{l}\text { 121 children aged } \\
8-12 \text { years old } \\
\text { (male: } 8.8 \%)\end{array}$ & $\begin{array}{l}\text { Assessment of the effects } \\
\text { of adult targeted food } \\
\text { commercials } \\
\text { (energy-dense and light } \\
\text { food products) on actual } \\
\text { intake in young children } \\
\text { while watching television } \\
\text { and the moderating effect } \\
\text { of maternal } \\
\text { encouragement on the } \\
\text { relation between } \\
\text { commercial condition and } \\
\text { food intake. }\end{array}$ & $\begin{array}{l}\text { A setting that } \\
\text { resembled a living } \\
\text { room was created } \\
\text { at school. Children } \\
\text { could freely eat from a } \\
\text { pre-weighed bowl with } \\
\text { chocolate-coated } \\
\text { peanuts, while } \\
\text { watching a 20-min } \\
\text { movie clip interrupted } \\
\text { by commercials of } \\
\text { different content across } \\
\text { the experimental } \\
\text { conditions. }\end{array}$ & $\begin{array}{l}\text { Snack food intake (in } \\
\text { g) during watching } \\
\text { television. }\end{array}$ & $\begin{array}{l}\text { Children who perceived } \\
\text { maternal encouragement } \\
\text { to be thin ate more when } \\
\text { exposed to light food } \\
\text { commercials compared to } \\
\text { neutral ads. } \\
\text { Children who perceived } \\
\text { no maternal } \\
\text { encouragement to be } \\
\text { thin ate more when } \\
\text { exposed to neutral } \\
\text { commercials compared } \\
\text { to either energy-dense } \\
\text { or light food commercials. } \\
\text { Neither commercial } \\
\text { condition nor maternal } \\
\text { encouragement to be }\end{array}$ \\
\hline
\end{tabular}




\begin{tabular}{|c|c|c|c|c|c|c|}
\hline & & & & & & $\begin{array}{l}\text { thin had a significant } \\
\text { main effect on food } \\
\text { intake. }\end{array}$ \\
\hline Harris 2009 & US & $\begin{array}{l}118 \text { children aged } \\
7-11 \text { years old } \\
\text { (male: } 62,52.5 \%)\end{array}$ & $\begin{array}{l}\text { Experiment testing } \\
\text { whether exposure to food } \\
\text { advertising during TV } \\
\text { viewing may prime, or } \\
\text { directly activate, an } \\
\text { automatic increase in } \\
\text { snack food consumption } \\
\text { in elementary-school-age } \\
\text { children. }\end{array}$ & $\begin{array}{l}\text { School or camp. The } \\
\text { children watched a } \\
\text { 14-min episode of a } \\
\text { cartoon, included } \\
\text { commercials: one-half } \\
\text { were randomized to the } \\
\text { "food commercial } \\
\text { condition" and one-half } \\
\text { to the "nonfood } \\
\text { commercial condition". } \\
\text { Children received a } \\
\text { pre-weighed bowl of } \\
\text { snacks to consume } \\
\text { while watching. }\end{array}$ & $\begin{array}{l}\text { Amount of snack foods } \\
\text { consumed }(\mathrm{g}) \text { during } \\
\text { TV advertising } \\
\text { exposure. }\end{array}$ & $\begin{array}{l}\text { The group exposed to } \\
\text { cartoon and ads ate } \\
\text { considerably more } \\
\text { snacks, compared to the } \\
\text { group exposed to non-food } \\
\text { advertisement. }\end{array}$ \\
\hline
\end{tabular}




\begin{tabular}{|c|c|c|c|c|c|c|}
\hline & & & & & & $\begin{array}{l}\text { condition than in the } \\
\text { neutral commercial } \\
\text { condition. }\end{array}$ \\
\hline Halford 2008 & UK & $\begin{array}{l}\text { 59 children aged } \\
9-11 \text { years old } \\
\text { (male: } 32,54.2 \%)\end{array}$ & $\begin{array}{l}\text { Assessment of the } \\
\text { influence of food } \\
\text { advertisement exposure on } \\
\text { caloric intake and food } \\
\text { preferences after TV } \\
\text { viewing. }\end{array}$ & $\begin{array}{l}\text { School. Children were } \\
\text { exposed to a collection } \\
\text { of } 10 \text { non-food or food } \\
\text { ads, followed by a } \\
\text { 10-min cartoon. After } \\
\text { viewing, each child was } \\
\text { presented with five } \\
\text { plates, containing one } \\
\text { of each of the five food } \\
\text { categories (low-fat } \\
\text { savory, low-fat sweet, } \\
\text { high-fat savory, high- } \\
\text { fat sweet, low density } \\
\text { energy) in either or a } \\
\text { standard portion size or } \\
\text { pre-weighed. They } \\
\text { could eat as little or as } \\
\text { much food as they } \\
\text { liked. The remaining } \\
\text { uneaten food was } \\
\text { re-weighed. }\end{array}$ & $\begin{array}{l}\text { Amount of food eaten } \\
\text { in kcal after } \\
\text { advertisement } \\
\text { exposure. }\end{array}$ & $\begin{array}{l}\text { Total energy intake was } \\
\text { significantly higher after } \\
\text { exposure to food } \\
\text { advertisements than after } \\
\text { the control (toy) } \\
\text { advertisements. } \\
\text { A significant interaction } \\
\text { with BMI status and } \\
\text { advertisement type was } \\
\text { observed. The significant } \\
\text { difference in intake } \\
\text { between the three } \\
\text { weight status groups was } \\
\text { in the food advertisement } \\
\text { condition only as all } \\
\text { participants consumed a } \\
\text { similar amount of food } \\
\text { following the control } \\
\text { (toy) advertisements. } \\
\text { Specifically, following } \\
\text { food ads, OB children } \\
\text { consumed more food } \\
\text { than the NW and OW } \\
\text { children. }\end{array}$ \\
\hline Halford 2007 & UK & $\begin{array}{l}93 \text { children aged } \\
5-7 \text { years old } \\
\text { (male: } 39,42 \%)\end{array}$ & $\begin{array}{l}\text { Assessment of the } \\
\text { influence of food } \\
\text { advertisement exposure on } \\
\text { caloric intake and food }\end{array}$ & $\begin{array}{l}\text { School. Children were } \\
\text { exposed to a collection } \\
\text { of } 10 \text { non-food or food } \\
\text { ads, followed by a }\end{array}$ & $\begin{array}{l}\text { Amount of food eaten } \\
\text { in kcal after food } \\
\text { advertisement exposure }\end{array}$ & $\begin{array}{l}\text { A main effect of } \\
\text { advertisement exposure } \\
\text { on total kcal intake was } \\
\text { found. Total kcal intake }\end{array}$ \\
\hline
\end{tabular}




\begin{tabular}{|c|c|c|c|c|c|c|}
\hline & & & $\begin{array}{l}\text { preferences after TV } \\
\text { viewing }\end{array}$ & $\begin{array}{l}\text { 10-min cartoon. After } \\
\text { viewing, each child was } \\
\text { presented with } \\
\text { pre-weighed individual } \\
\text { servings of five food } \\
\text { categories (low-fat } \\
\text { savory, low-fat sweet, } \\
\text { high-fat sweet, high-fat } \\
\text { savory and fruit). They } \\
\text { could eat as little or as } \\
\text { much food as they } \\
\text { liked. The remaining } \\
\text { uneaten food was } \\
\text { re-weighed. }\end{array}$ & & $\begin{array}{l}\text { was significantly higher } \\
\text { after exposure to food } \\
\text { advertisements (FA) than } \\
\text { after the non-food } \\
\text { advertisements (NA). } \\
\text { There was no main } \\
\text { effect of weight status } \\
\text { on intake despite the } \\
\text { fact that mean intake in } \\
\text { the overweight and the } \\
\text { obese children was } \\
\text { higher in both } \\
\text { experimental conditions } \\
\text { (692.1 in the FA } \\
\text { condition; 594.9 in the } \\
\text { NA condition), nor was } \\
\text { there any significant } \\
\text { interaction with weight } \\
\text { status. }\end{array}$ \\
\hline
\end{tabular}




\begin{tabular}{|l|l|l|l|}
\hline & & & $\begin{array}{l}\text { sweet, high-fat sweet, } \\
\text { high-fat savory). They } \\
\text { could eat as little or as } \\
\text { much food as they } \\
\text { liked. The remaining } \\
\text { uneaten food was re- } \\
\text { weighed. }\end{array}$ \\
\hline
\end{tabular}

sweet, high-fat sweet

high-fat savory). They

could eat as little or as

uneaten food was re- 
Table 3. Quality Assessment of the Included Studies

\begin{tabular}{|l|l|l|}
\hline Study & Study design & Quality score \\
\hline Anschutz 2009 & RCT & 2 \\
\hline Halford 2004 & Counterbalanced design & 1 \\
\hline Halford 2007 & Counterbalanced design & 1 \\
\hline Anschutz 2010 & RCT & 2 \\
\hline Dovey 2011 & Counterbalanced cross-over & 1 \\
\hline Harris 2009 & study & \\
\hline Halford 2008 & RCT & 2 \\
\hline
\end{tabular}

